(C) Copyright 2020: Editum. Servicio de Publicaciones de la Universidad de Murcia. Murcia (Spain) ISSN print edition: 0212-9728. ISSN online edition (http://revistas.um.es/analesps): 1695-2294. Online edition License Creative Commons 4.0: BY-SA

\title{
Optimism and happiness in undergraduate students: Cognitive flexibility and adjustment to university life as mediators
}

\author{
Ayşe Sibel Demirtaş
}

Alanya Alaaddin Keykubat University (Turkey)

\begin{abstract}
Título: Optimismo y felicidad en estudiantes universitarios: flexibilidad cognitiva y adaptación a la vida universitaria como mediadores.

Resumen: De acuerdo con el objetivo del enfoque de psicología positiva, este estudio fue diseñado para construir una comprensión de las relaciones entre optimismo, flexibilidad cognitiva, ajuste a la vida universitaria y felicidad mediante la propuesta de un modelo de mediación múltiple. Un total de 386 estudiantes universitarios ( $64 \%$ mujeres y $36 \%$ hombres) entre 18 22 años participaron en el estudio. Los participantes fueron reclutados de una pequeña universidad en Turquía. El Test de Orientación de Vida, el Inventario de Flexibilidad Cognitiva, la Escala de Vida Universitaria y el Formulario Corto del Cuestionario de Felicidad de Oxford fueron utilizados como medidas. Los resultados mostraron que el optimismo, la flexibilidad cognitiva, el ajuste a la vida universitaria y la felicidad se correlacionan positivamente. Los resultados de los análisis mediacionales también indicaron que la mediación serial múltiple de la flexibilidad cognitiva y el ajuste a la vida universitaria en el modelo hipotetizado fue estadísticamente significativa y explicaron aproximadamente el $50 \%$ de la varianza en la felicidad.

Palabras clave: optimismo, felicidad, flexibilidad cognitiva, adaptación a la vida universitaria.
\end{abstract}

\section{Introducción}

Positive psychology approach, which emphasizes the strengths of a person and maximizes human functionality, seeks to understand the factors affecting the development of individuals and communities for the discovery and promotion of human strengths (Seligman, 2002). The essential propose of this approach is to understand and enhance wellbeing. In the literature, well-being and happiness are often used interchangeably (Theobald \& Cooper, 2012). The World Health Organization (2004) defines well-being as "positive mental health," while some researchers have described wellbeing as "happiness" (Linley, Maltby, Wood, Osborne, \& Hurling, 2009). For example, Mroczek and Kolarz (1998) see happiness as a synonym of well-being. Further, there are some systematic explanations of happiness. Hedonic well-being, also known as subjective well-being, is defined as positive emotions and mental experiences that occur frequently, negative emotions and moods being rarely experienced, and a high level of life satisfaction (Diener, 1984). The eudaimonic perspective of well-being, conceptualized by the psychological well-being model of Ryff (1989), describes eudaimonia ("eu" = good and "daimon" = spirit) with terms like welfare, happiness, and flourishing while focusing on how individuals struggle to demonstrate full functionality and gain awareness of their unique talents. Other researchers have conceptualized happiness as including three constituents: “1) the fre-

* Correspondence address [Dirección para correspondencia]:

Ayşe Sibel Demirtaş, Ph.D., Alanya Alaaddin Keykubat University, Faculty of Education, Department of Psychological Counseling and Guidance, Alanya, Antalya (Turkey). E-mail: asibeldemirtas@gmail.com

(Article received: 28-5-2019; revised: 13-9-2019; accepted: 17-12-2019)
Abstract: In accordance with the goal of the positive psychology approach, this study was designed to build an understanding of the relationships among optimism, cognitive flexibility, adjustment to university life and happiness by proposing a multiple mediation model. A total of 386 undergraduates (64\% female and 36\% male) between 18-22 years participated in the study. The participants were recruited from a small university in Turkey. The Life Orientation Test, Cognitive Flexibility Inventory, University Life Scale, and Oxford Happiness Questionnaire Short Form were utilized as measures. The results showed that optimism, cognitive flexibility, adjustment to university life, and happiness positively correlated. The findings from the mediational analyses also indicated that the serial multiple mediation of cognitive flexibility and adjustment to university life in the hypothetical model was statistically significant and explained approximately $50 \%$ of the variance in happiness.

Keywords: optimism, happiness, cognitive flexibility, adjustment to university life.

quency and degree of positive affect, or joy, 2) the average level of satisfaction over a period, and 3) the absence of negative feelings, such as depression and anxiety" (Argyle \& Lu, 1990, p. 1012).

Happiness literature has provided considerable evidence regarding the correlates of this positive construct in college students. For example, Flynn and Macleod (2015) revealed that self-esteem and academic success are important predictors of students' happiness. Cheng (2001) found, on a sample of first-year undergraduate students, that an optimistic attributional style (especially in positive situations) correlated with happiness. It was also demonstrated that self-liking, self-competence, and cognitive reappraisal contributed the most to the happiness of university students (Demirtaş, 2018). Other studies found that happiness was associated with a number of variables, such as motivational orientation, efficacy beliefs, personality traits, and sustainable behavior (Asıc1 \& İkiz, 2015; Choi, 2016; Doğan, 2013; Lee \& Padilla, 2016; Nowell, 2017; Pacheco \& Kamble, 2016; Ziapour, Khatony, Jafari, \& Kianipour, 2018).

These findings suggest that the research concerning the contributing factors on happiness has important outcomes in understanding positive youth development. To our knowledge, although the connection between optimism and happiness is well researched, their associations with cognitive flexibility and adjustment to university life have not been well studied. As the association between these variables are considered to have crucial effects on undergraduates' happiness, it was supposed that cognitive flexibility and adjustment to university life could mediate the relation between optimism and happiness (Figure 1). 


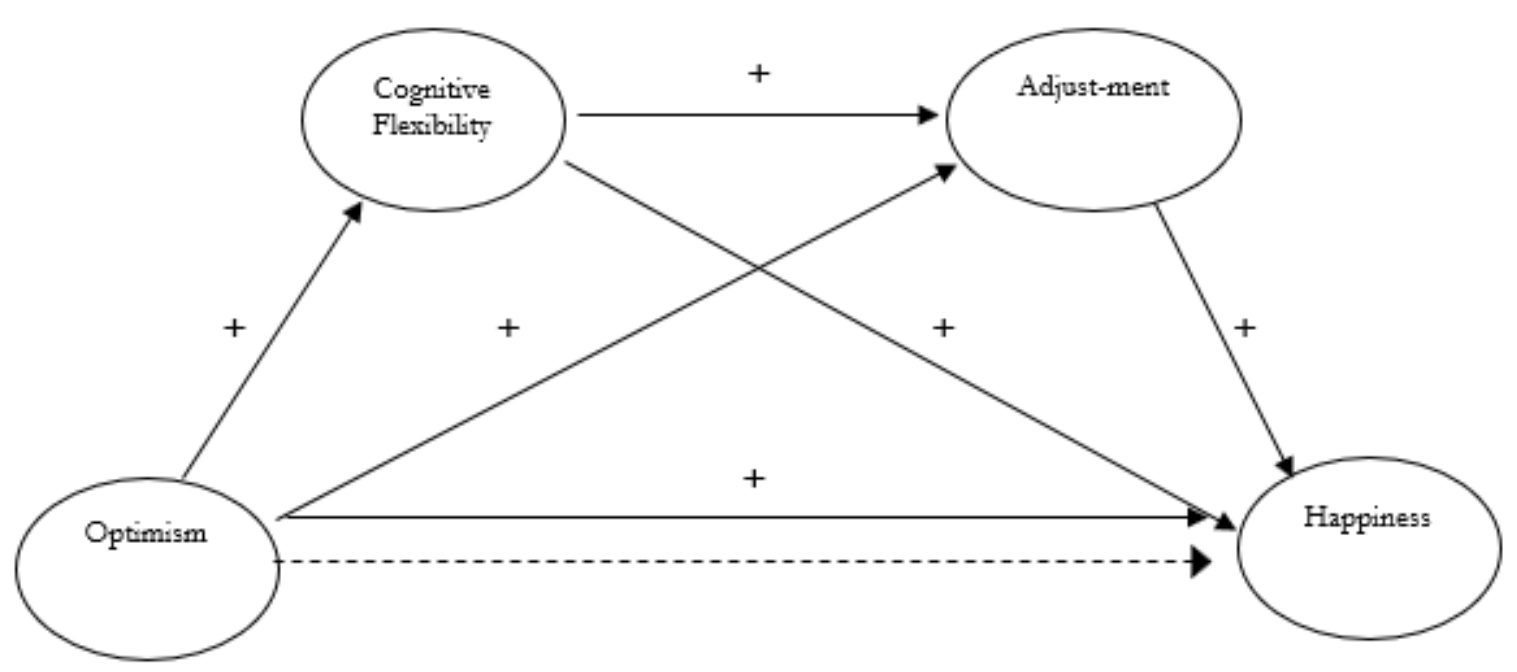

Figure 1. Hypothesized Model.

\section{Optimism and Happiness}

One personal characteristic connected to happiness is optimism. Dispositional optimism, which is rooted in the behavioral self-regulation model theorized by Scheier and Carver (1988), is conceptualized as "the tendency to believe that one will generally experience good vs. bad outcomes in life" (Scheier \& Carver, 1992, p. 203). If people believe in favorable outcomes, they have the confidence to maintain their efforts to achieve their goals even if they encounter obstacles (Carver \& Scheier, 1990). The important role that expectations play in this model has led to the exploration of the behavioral and emotional effects of individual differences in optimism and pessimism (Scheier, Carver, \& Bridges, 1994). Studies on optimism have provided ample evidence that it has many beneficial qualities linking the quality of life and plays an essential role on physical and mental health (Seligman \& Csikszentmihalyi, 2000). Previous studies have also showed that optimism predicts physical well-being (Wimberly, Carver, \& Antoni, 2008), life satisfaction (Leung, Moneta, \& McBride-Chang, 2005), subjective well-being (Isaacowitz, 2001; Daukantaite \& Bergman, 2005; Vazquez, 2009; Sahai \& Singh, 2017; Duy \& Yıldız, 2017), psychological well-being (Coups, 2003; Heo, Chun, Lee, \& Kim, 2016) and emotional well-being (Matthews \& Cook, 2009). The association between optimism and well-being is considered to be a function of the effective coping strategies used by optimistic individuals (Conversano et al., 2010), and experience more positive emotions (Carver \& Scheier, 2014).

\section{Cognitive Flexibility}

Based on the above explanations, this study proposes another psychological construct, "cognitive flexibility", that may reveal the association between optimism and happiness. Research suggest that the core constituent of cognitive flexi- bility is "the ability to switch cognitive sets to adapt to the changing environmental stimuli" (Dennis \& Vander-Wal, 2010, p. 242). Martin and Rubin (1995), defined this construct as an individual's "(a) awareness that in any given situation, there are options and alternatives available, (b) willingness to be flexible and adapt to the situation, and (c) selfefficacy in being flexible" (p. 1). Cognitive flexibility refers to the ability of individuals to think and deal with different views in flexible styles and regulate their problem-solving plans as the demands of the task change (Al Jabari, 2012; De Dreu, Baas, \& Nijstad, 2008). Previous studies have found that cognitive flexibility has been positively related to better psychological health, including negative mood states (Kato, 2012), psychological well-being (Cardom, 2016; Fu \& Chow, 2017), interpersonal competence (Rubin \& Martin, 1994), life satisfaction (Çikrıkci, 2018), and happiness (Asıc1 \& İkiz, 2015).

Although there is very limited research (e.g. Doğan-Laçin \& Yalçın, 2018; Sapmaz \& Doğan, 2013) to support the direct link between optimism and cognitive flexibility, the positive affect that accompanies optimism is considered to be associated with cognitive flexibility that encourages the generation of multiple solutions to everyday problems (Johnson, Waugh, \& Fredrickson, 2010). Optimism promotes cognitive flexibility, suggesting that thinking more about positive outcomes enhances individuals' awareness of the available cognitive alternatives and to control the course of their actions, even in times of adversity. Generalized positive outcome expectancies stemming from optimism are considered to enhance cognitive flexibility, reduce negative emotions, and develop resilience against distress (Cousins, Tomlinson, Cohen, \& McMurtry, 2016). Research suggest that optimists generally believe they can overcome any obstacle, appraise stressful issues more positively and use task-oriented coping strategies (Carver, Scheier, \& Segerstrom, 2010; Chang, 1998;). 


\section{Adjustment to University Life}

Transitioning to university can be difficult for some students because it is a time when individuals separate from their homes and families, interact with unfamiliar people and cultures, confront many new interpersonal, social, and academic demands, and feel confused related to emerging adulthood (Arnett, 2000; Benn, Harvey, Gilbert, \& Irons, 2005). Research suggest that such a time is stressful for many students (Dyson \& Renk, 2006; Pritchard, Wilson, \& Yamnitz, 2007; Schilds, 2002). Furthermore, this process is not limited to the early period but continues throughout university life. Baker and Siryk (1984) defined adaptation to university as a multidimensional concept including four dimensions: academic, social, personal-emotional adjustment, and goal commitment-institutional attachment. Adjustment to university life has been considered as an important outcome and have consequently investigated a broad range of factors as its possible predictors (Crede \& Niehorster, 2012), including motivational orientations (Baker, 2004), openness to new friendships and friendship quality (Buote et al., 2007), achievement motivation and self-efficacy (Elias, Noordin, \& Mahyuddin, 2010), psychological hardiness (Sürücü \& Bacanl, 2010), and resilience (Kaba \& Keklik, 2016; Rahat \& İlhan, 2015).

Research has also provided evidence that optimism plays a vital role in adaptation to university life. Pritchard et al. (2007) found in a longitudinal study that optimism was the best predictor of physical and psychological outcomes in university adjustment. Perera and McIlveen (2014) also revealed the predictor role of optimism on the higher use of active coping and better psychological adjustment to college transition. Research suggest that optimistic undergraduates are less likely to see education as a source of stress (Krypel \& Henderson-King, 2010). A recent study by Nurttila, Ketonen and Lonka (2015) showed that optimistic undergraduates reported the lowest task avoidance and highest competence in terms of achievement strategies. Cabras and Mondo (2018) found that optimism was positively correlated to taskoriented coping and life satisfaction of Italian freshmen. These findings suggest that the advantage of optimistic students in their adjustment to university life is a function of their characteristic effective coping style.

Cognitive flexibility is other construct that is closely associated with adjustment to university life. A high level of cognitive flexibility has been associated with a significant decrease in emotional stress using cognitive reappraisal and constructive thinking (Johnco, Wuthrich, \& Rapee, 2014). These characteristics are effective in protecting the undergraduates from stress and negative experiences, both in academic adjustment and personal-social adjustment. Increased levels of cognitive flexibility are also associated with interpersonal communication competence (Martin \& Rubin, 1995), more extroversion, more self-control, more openness for improvement (Bilgin, 2017), and a higher likelihood of using problem focused coping (Zhang, 2011). Cognitive flex- ibility enables greater success in achieving desired goals (Tamir, 2009) and reduces the impact of negative experiences (Hirt, Devers, \& McCrea 2008) by allowing an individual to generate ideas and consider alternative perspectives in order to adapt to changes in the environment (Johnson, 2016). In conjunction with this notion, cognitive flexibility correlated to the variables including problem-solving skills, study strategies, openness to change, academic performance, selfefficacy, and effective decision-making, which are closely associated with adjustment to university life (Bilgin, 2009; Lin, 2013; Gürbüz \& Nartgün, 2018; Isen, 2000; Önen \& Koçak, 2015). Bing (2011) also found, on a sample of 597 college students, that cognitive flexibility could predict school adaptation well. These findings suggest that adjustment seems to be related to the ability to deal with the academic, social, personal-emotional, and environmental challenges took in attending university.

\section{The Current Study}

Emerging adulthood is a critical period in lifelong development (Arnett, 2000). Undergraduate students confront with various life transitions and have to make decisions about their future and take on new roles and responsibilities. Therefore, this period of development, in which individuals experience a lot of change in their lives, is related to a high risk of mental health (Gore \& Aseltine, 2003). Based on the theoretical support and explanations above, the prediction of the current study was that optimistic students would have high cognitive flexibility, deal with problems well, and adapt to changing environments easily and, as a result, would be more likely to be happy.

\section{Method}

\section{Participants}

A total of 386 undergraduates, 64\% females and 36\% males aged between 18 and 22 years, participated in the study. The participants of the current study comprised 175 freshmen, 125 sophomores, 66 juniors, and 20 seniors who were attending the Faculty of Education. A convenience sample of undergraduates from a small university in Turkey was used. The university is located in one of the touristic town on the southern coast of Turkey.

\section{Procedure}

Accordingly, the ethical principles, permission was received from the University Research Ethics Committee. All the students voluntarily participated in the research (not given extra credit or compensation) in classroom settings. The data were collected at the beginning of first term (fall) of the 2017-2018 academic year. The following measure were utilized in the study. 


\section{Instruments}

\section{Life Orientation Test}

The test, assesses individuals' differences in dispositional optimism versus pessimism, includes 12 items with 4 items phrased optimistically, 4 items phrased pessimistically, and 4 items using as fillers (Scheier \& Carver, 1985). A sample item of optimism is "In uncertain times, I usually expect the best," an example of pessimism is "I hardly ever expect things to go my way," and an example of filler is "It's important for me to keep busy." The scale has been reported to have adequate internal consistency (Cronbach's $\alpha=.76$ ) and 4 -week retest reliability (.79) (Scheier \& Carver, 1985). The scale is suitable for calculating a unidimensional score such as life orientation. High scores indicate high life orientation. Aydin and Tezer (1991) adapted the test to the Turkish culture, which is the version used in this study. The criterion validity of the test was assessed with Beck Depression Inventory in two groups, and the correlation coefficients were found to be $r=-.56$ and $r=-.45$, respectively. Cronbach's alpha coefficient was found to be $.72(N=150)$, and the test-retest correlation was found to be $.77(N=97)$ (Aydin \& Tezer, 1991). In the current research, Cronbach's alpha coefficient was calculated as .80 .

\section{Cognitive Flexibility Inventory}

The inventory was designed to measure three aspects of cognitive flexibility: "the tendency to perceive difficult situations as controllable; the ability to perceive multiple alternative explanations for life occurrences and human behavior; and the ability to generate multiple alternative solutions to difficult situations" (Dennis \& Vander Wal, 2010, p. 241). The reliability and validity study of the scale in Turkish culture was carried out by Gülüm and Dağ (2012). The exploratory factor analysis showed that the two-factor structure of the scale has the same psychometric properties as its original form. Cronbach's alpha coefficients were found to be .89 for alternatives, .85 for control, and .90 for total. In addition, on a sample composed of 549 undergraduates, Doğan-Laçin (2015) found the values of the confirmatory factor analysis of the scale to be: $x^{2}=798.48, \mathrm{df}=169$, RMSEA $=.08$, $\mathrm{NFI}=.95, \mathrm{CFI}=.96, \mathrm{RMR}=.08$. In the current study, the total score was obtained and used. Cronbach's alpha coefficient was calculated as .84 .

\section{Adjustment to University Life Scale}

The scale was developed in order to evaluate the adjustment to university life in terms of personal, social, and academic dimensions (Aslan, 2015). In evaluating the psychometric properties of the scale, exploratory and confirmatory factor analyses were carried out with 488 undergraduate students (Aslan, 2015). The exploratory factor analysis revealed that the scale consisted of 60 items and 3 factors (personal, social, academic) and explained $78.16 \%$ of the total variance. The factor loadings for the items were between .33 and .77. A confirmatory factor analysis showed a three-factor structure with an acceptable overall fit: $x^{2}=5787.98, \mathrm{df}=$ $1707, \mathrm{RMSEA}=.08, \mathrm{NFI}=.93, \mathrm{CFI}=.93$, and $\mathrm{RMR}=.07$. Cronbach's alpha coefficients were calculated as .92, .89, and .93 , and test-retest coefficients were calculated as $.82, .61, .84$ respectively. Aslan (2015) reported that the scale's threefactor structure presented satisfactory validity and reliability results for Turkish university students. In the current study, the total score was used. Cronbach's alpha coefficient was calculated as .93.

\section{Oxford Happiness Questionnaire Short Form}

The questionnaire is an 8-item measure designed to evaluate the level of happiness (Hills \& Argyle, 2002). Doğan and Akıncı-Çötok (2011) evaluated the psychometric properties of the OHQ-S in Turkish culture. The exploratory factor analysis revealed that the one-factor structure explained $39.74 \%$ of the total variance and that the factor loadings for the items were between .53 and .72 . The confirmatory factor analysis showed a one-factor structure with a good overall fit: $x^{2}=36.05, \mathrm{df}=13, \mathrm{AGFI}=.93, \mathrm{GFI}=.97, \mathrm{RMSEA}=.07$, $\mathrm{NFI}=.92, \mathrm{CFI}=.95$, and $\mathrm{RMR}=.04$. Cronbach's alpha coefficient of the scale was calculated as .74 , and the test-retest correlation was found as .85. It was reported that the scale's one-factor structure presented satisfactory psychometric properties in evaluating Turkish university students' happiness (Doğan \& Akıncı-Çötok, 2011). In the current research, Cronbach's alpha coefficient was calculated as. 78 .

\section{Statistical Analyses}

Descriptive statistics, Pearson's correlation method, an approach based on Ordinary Least Squares Regression, and Bootstrapping were used in the analyses of the data. Mahalanobis distance values were calculated in order to determine outliers and 4 outliers were deleted as they exceeded the chi-square critical value. The analyses were conducted with 382 observations. The values of kurtosis and skewness were calculated to prove normal univariate distribution. As the values of skewness and kurtosis showed acceptable ranges in the region of -1 to +1 (optimism: skewness -.34, kurtosis: .21; cognitive flexibility: skewness .13, kurtosis: -.31; adjustment to university life: skewness .13, kurtosis .33; happiness: skewness -.19 , kurtosis .00), it was concluded that the scores did not show a significant deviation from the normal distribution (Tabachnick \& Fidell, 2013).

A multiple mediation model which involves "simultaneous mediation by multiple variables" (Preacher \& Hayes, 2008 , p. 880), was also used in the present study. Hayes (2009) state "if zero is not between the lower and upper bound, then the analyst can claim that the indirect effect is not zero with ci\% confidence."(p. 412). In addition, a contrast test was used to determine specific indirect of the vari- 
ables and stronger mediators in the model. The Bootstrapping analyses of the study were conducted by "Multiple Mediation Model 6" through PROCESS Macro 3 using IBM SPSS 24.0 (Hayes, 2017). A P-value of .05 is considered on the borderline of statistical significance.

\section{Results}

\section{Descriptives and Correlations}

Pearson's correlation coefficients were utilized to determine the relationships among the variables. The means, standard deviations, and correlations are presented in Table 1.

Table 1. Descriptive statistics and Pearson correlation coefficients related to research variables

\begin{tabular}{|c|c|c|c|c|c|c|c|c|}
\hline Variables & Mean & Mean & Kurtosis & Skewness & 1 & 2 & 3 & 4 \\
\hline 1. Optimism & 26.06 & 5.89 & .22 & -.34 & $\begin{array}{ll}-- \\
--\end{array}$ & & & \\
\hline 2. Cognitive Flexibility & 88.87 & 11.38 & -.31 & .13 & $.40 * *$ & --- & & \\
\hline 3. Adjustment & 214.87 & 28.47 & .33 & .13 & $.37 * *$ & $.31 * *$ & --- & \\
\hline 4. Happiness & 22.90 & 4.88 & .00 & -.19 & $.65 * *$ & $.37 * *$ & $.48 * *$ & -- \\
\hline
\end{tabular}

$N=382, * * p<.01$

Table 1 shows that optimism is positively correlated with cognitive flexibility, adjustment to university life, and happiness. Cognitive flexibility is positively correlated with adjustment to university life and happiness. There is also a positive correlation between adjustment to university life and happiness.

\section{Mediation Model Analyses}

The findings for the serial mediating roles of cognitive flexibility and adjustment to university life in the relationship between optimism and happiness are presented in Figure 2.

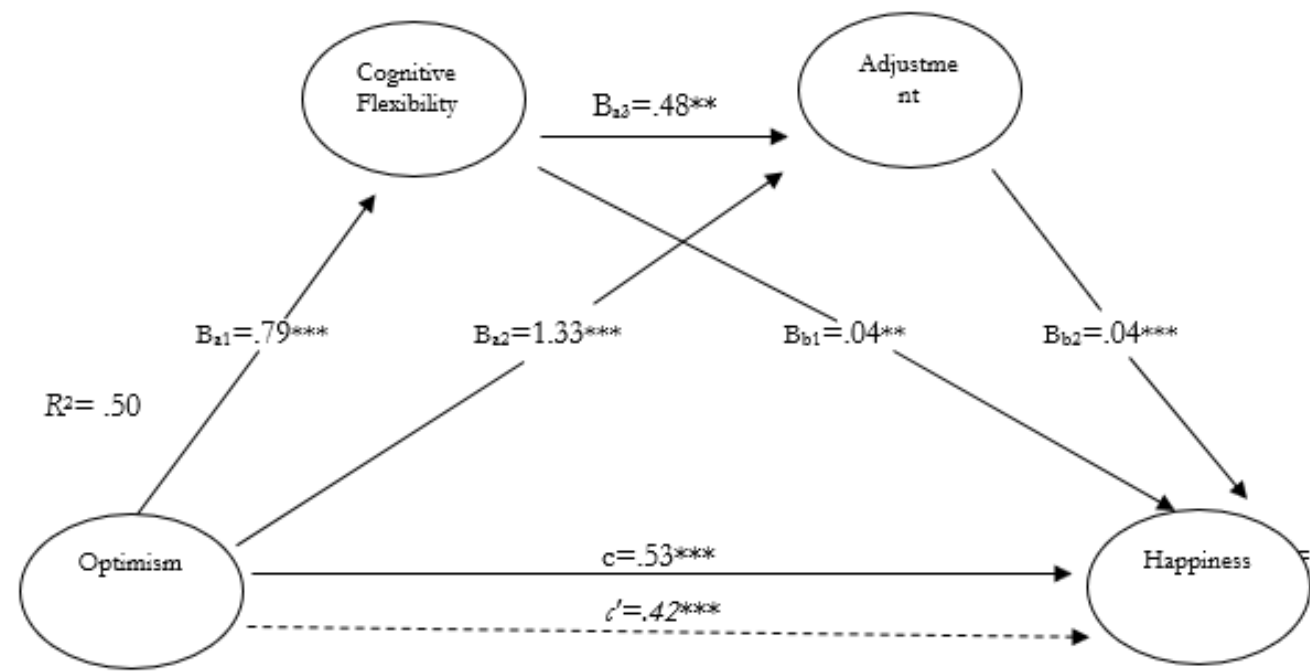

Figure 2. The Serial Mediation of Cognitive Flexibility and Adjustment to University Life in the Relationship between Optimism and Happiness.

As presented in Figure 2, the total effect of optimism on happiness is statistically significant $(c=.53, \mathrm{SE}=.03 ., t=$ $16.46, p<.001)$ (step 1). The direct effects of optimism on cognitive flexibility $(B=.79, \mathrm{SE}=.09, t=8.75, p<.001)$ and adjustment to university life $(B=1.33, \mathrm{SE}=.24, t=5.37, p<$ $.001)$ are statistically significant, as well as the direct effect of cognitive flexibility (the first mediating variable) on adjustment to university life (the second mediating variable) ( $B=$ $.48, \mathrm{SE}=.12, t=3.81, p<.001)$ (step 2$)$. In addition, the direct effects of cognitive flexibility $(B=.04, \mathrm{SE}=.01, t=$ $2.35, p<.01)$ and adjustment to university life $(B=.04$, SE $=.00, t=6.46, p<.001)$ on happiness is also significant (step 3). When optimism and two mediating variables were entered simultaneously into the equation (step 4), the signifi- cant relationship between optimism and happiness decreased, but the significance level did not change $\left(c^{\prime}=.42, \mathrm{SE}\right.$ $=.03, t=12.22, p<.001)$. These results support the mediational hypothesis. The model is significant $\left(\mathrm{F}_{(5-376)}, p<.001\right)$ and explained approximately $50 \%$ of the variance in happiness.

\section{Indirect Effects of Optimism on Happiness through Cognitive Flexibility and Adjustment to University Life}

The comparison of the direct and specific indirect effects of undergraduates' optimism on happiness through cognitive flexibility is presented in Table 2. 
The indirect effects were tested using bootstrapping with 10,000 bootstrap samples. The estimates were taken within $95 \%$ confidence intervals, and the bias corrected and accelerated results are presented in Table 2 . Because of the unequal distribution of men and women in the sample, gender was used as a covariate in the analyses. The total indirect effect (the difference between the total and indirect effects /cc') of optimism through cognitive flexibility and adjustment on happiness were statistically significant (point estimate $=$
.1110 and $95 \%$ BCa CI $[.0724, .1540])$. In addition, the mediators in the hypothesized model were examined individually. The results revealed that the mediation of cognitive flexibility (point estimate $=.0329$ and $95 \%$ BCa CI [.0060, $.0656]$ ), the mediation of adjustment to university life (point estimate $=.0608$ and $95 \%$ BCa CI $[.0325, .0920])$, and the multiple mediation of cognitive flexibility and adjustment to university life (point estimate $=.0174$ and $95 \%$ BCa CI $[.0066, .0316])$ were also statistically significant.

Table 2. The comparison of direct and specific indirect effects of optimism on happiness through cognitive flexibility and adjustment to university life

\begin{tabular}{|c|c|c|c|c|}
\hline \multirow{2}{*}{$\begin{array}{l}95 \% \text { Bca Confidence Interval } \\
\text { Effects }\end{array}$} & \multicolumn{2}{|c|}{ Product of coefficients } & \multicolumn{2}{|c|}{ Bootstrapping } \\
\hline & Point Estimate & $\mathrm{SE}$ & Lower & Upper \\
\hline Total Indirect Effects & .1110 & .0207 & .0724 & .1540 \\
\hline Opt $\rightarrow$ Cog. Flex. $\rightarrow$ Happ. & .0329 & .0153 & .0060 & .0656 \\
\hline Opt. $\rightarrow$ Adjust. $\rightarrow$ Happ. & .0608 & .0153 & .0325 & .0920 \\
\hline Opt. $\rightarrow$ Cog. Flex $\rightarrow$ Adjust. $\rightarrow$ Happ. & .0174 & .0063 & .0066 & .0316 \\
\hline Contrasts & & & & \\
\hline Model 1 versus Model 2 & -.0279 & .0238 & -.0731 & .0202 \\
\hline Model 1 versus Model 3 & .0155 & .0160 & -.0140 & .0487 \\
\hline Model 2 versus Model 3 & .0434 & .0163 & .0133 & .0765 \\
\hline
\end{tabular}

corrected and accelerated 10,000 bootstrap samples, Model 1= Optimism - Cognitive Flexibility - Happiness; Model 2= Optimism - Adjustment to University Life - Happiness; Model 3= Optimism - Cognitive Flexibility - Adjustment to University Life - Happiness.

Finally, the strength of the individual indirect effects against each other were compared. In the first comparison, model 1 (mediation of cognitive flexibility) was not statistically different from model 2 (mediation of adjustment). In the second comparison, model 1 (mediation of cognitive flexibility) was not statistically different from model 3 (serial multiple mediation of cognitive flexibility and adjustment). Based on a $95 \%$ BCa confidence interval, within the statistically significant comparison, model 2 (mediation of adjustment) was stronger than model 3 (serial multiple mediation of cognitive flexibility and adjustment). The indirect effect via adjustment to university life is greater than the effect via the two other indirect effects.

\section{Discussion}

The findings showed that the mediation of cognitive flexibility and adjustment to university life were statistically significant in the model. Also, the mediational hypothesized model had significant levels and explained approximately $50 \%$ of the variance in happiness. The findings of the model comparisons also revealed that the mediation of adjustment to university life was stronger than the others.

\section{Relationship between optimism and happiness}

Consistent with prior research, optimism was found to be associated with happiness in this study. High optimistic individuals are considered to have better moods, to be stable, and also to be in better physical health (Peterson, 2000). Due to the fact that optimism promotes a healthy lifestyle, adaptive and constructive reactions, action-oriented problem solving, and flexible moods, it has important implications for both mental well-being and physical well-being (Conversano et al., 2010). The findings of the current research confirm these earlier studies in literature. For example, Pacheco and Kamble (2016) found that optimism was positively correlated to positive affect, happiness, and life satisfaction and negatively correlated to negative affect and depression. Marrero, Carballeira, and González (2014) reported that optimism is a relevant personality trait to improve the subjective well-being of undergraduates. Yue, Hao, and Goldman (2010) also found that optimism was negatively correlated with psychological distress symptoms in undergraduates. The advantage of well-being for optimistic people is considered to be a function of their characteristic coping style. Research has provided evidence that optimistic students generally deal with stress in a more active way than pessimistic students (Ji \& Zhang, 2011). Shapira and Mongrain (2010) conducted an experimental study in which the effectiveness of an optimism exercise was compared with a control group in a large non-clinical Canadian sample. Regardless of initial happiness levels, study findings showed that the participants in the optimism intervention group were happier than those control group. These studies confirm the hypothesized model of the current study in which optimism is the predictor variable. Seligman's view on optimism (1990) also explains why optimists are happy. According to "learned optimism" approach of Seligman (1990), optimists have characteristic explanatory style about the causes of the events. Optimists provide good events to lighten every field of their lives. Furthermore, the other reason why optimistic people are happy is that they have generally active coping strategies to come up with the stressful situations. For example, Hanssen et al. (2014) confirmed that motivational coping served to mediate the relationship between optimism and all indices of well-being. 


\section{Mediating roles of cognitive flexibility and adjust- ment to university life}

In the current research, optimism was found to be associated with cognitive flexibility. The association between optimism and cognitive flexibility is considered to be a function of positive outcomes stemming from optimism. This positive personality trait promotes cognitive flexibility, suggesting that thinking more about positive outcomes enhances individuals' abilities to perceive difficult situations as controllable and to generate multiple alternative solutions to difficult situations which in turn allows them to be flexible and open to new alternatives.

Consistent with prior research, optimism was also found to be associated with adjustment to university life in this study. Optimistic individuals have a disposition to hold positive expectations for the future and maintain their efforts to reach their personal goals. Optimism also has a cognitive construct that relates to motivation: optimists use effort, whereas pessimists disengage from effort (Carver \& Scheier, 2014). Because of their positive, goal-oriented view, their level of motivation is high (Ben-Zur, 2003). These characteristics are effective in academic, personal, and social adjustment to university life.

The present results also reveal that cognitive flexibility and adjustment to university life, the mediators in the current research, were found to be related. This finding confirms earlier studies in the literature. For example, on a sample of 597 colleague students, Bing (2011) found a positive correlation between cognitive flexibility and school adaptation. The transition to university is a time when individuals separate from their homes and families, interact with unfamiliar people and cultures, and are confronted with many new interpersonal, social, and academic demands (Benn et al., 2005). People with cognitive flexibility believe they can succeed in communication in different situations, they are enthusiastic to try new ways of communication, and they adapt to meet their needs when they encounter unusual situations (Martin \& Anderson, 1998). Cognitive flexibility is associated with using various thinking strategies and mental frameworks. Individuals with cognitive flexibility have the ability to investigate the environment to identify changes as they occur and create multiple strategies to prepare for whatever may develop (Gurvis \& Calarco, 2007). Based on these explanations, it can be concluded that cognitively flexible undergraduates view themselves as competent to cope with new interpersonal, social, and academic demands in adjustment to university life.

In the current research, the predictor role of cognitive flexibility on happiness was found to be statistically significant. Cognitive flexibility is essential for individuals to successfully challenge and change maladaptive thoughts with adaptive thinking. Individuals with high cognitive flexibility are better equipped to consider and employ various coping strategies in order to resolve situations and reduce distress (Johnson, 2016). The findings of a similar study by As1c1 and
İkiz (2015) confirmed that the level of cognitive flexibility is associated with greater happiness. Similar with optimistic people, the advantage of happiness in cognitively flexible people may be considered a function of their characteristic coping style. Fu and Chow (2017) investigated the effect of earthquake experiences on psychological well-being and the potential moderating role of cognitive flexibility on the relationship between earthquake experiences and psychological well-being on adolescents. The authors reported that adolescents with high levels of cognitive flexibility may better tolerate uncertainty in life, think in constructive ways about the earthquake experience, and deal with challenges in an effective way and that all these processes promote their psychological well-being.

Findings from the model comparisons revealed that the indirect effect on adjustment to university life is greater than the effect of the two other mediators. Individual differences in adjustment to university life seem to be important. Even though some students experience this transition as a challenge for their personal development, this process is stressful for many students (Dyson \& Renk, 2006; Shields, 2001). Individual characteristics such as personality traits, resilience, openness to new friendship, and self-efficacy have been shown play a significant role in adjustment to university life (Buote et al., 2007; Elias et al., 2010; Halamandris \& Power, 1996; Kaba \& Keklik, 2016 ; Rahat \& Illhan, 2015). The findings of the current research indicate that individual differences in optimism have significant predicting roles for adjustment to university and the happiness of undergraduates. This finding confirms earlier studies in the literature. With the help of adaptive direction of objectives and using constructive coping strategies, optimistic people are expected to be more successful, especially in difficult situations and complex tasks (Conversano et al., 2010). Optimists perceive things in the best possible light and work harder and more efficiently (Carver et al., 2010). These characteristics have the effect of reducing their stress and negative experiences. Research also suggest that optimism predicts not only better physical outcomes but also better psychological outcomes in university adjustment (Pritchard et al., 2007). The advantages of adjustment and well-being in optimistic people are considered a function of their characteristic coping style. In a study by Herrmann (2007), active coping strategies of the optimists mediated the relationship between optimism and adjustment to college life. Researchers have stated that such coping abilities should, in turn, lead to more positive physical and mental health outcomes (Koesten, Schrodt, \& Ford 2009). According to Gabrys, Tabri, Anisman and Matheson (2018) in the context of a stressful situation, cognitive flexibility provides generating multiple coping strategies and adjusting flexibly according to changing stressor demands. A respectable literature implies that people who have positive expectations about the future see difficulties as obstacles to overcome, so they behave in more adaptive ways in adverse conditions than pessimistic people (Carver et al., 2010). Both cognitive flexibility and optimism play an important role in 
an individual's ability to cope with circumstances that are deemed to be challenging.

Finally, it could be concluded that optimistic students may use cognitive alternatives (cognitive flexibility) stemming from their positive expectations or cognitively flexible students have motivations and alternatives to control the course of their actions in most situations; thus they may adjust better to changed or new task demands and situations and might be happier.

\section{Limitations}

The most important limitation of the research is the cross-sectional design as the causal relationships cannot be concluded. Future research will therefore need to involve experimental studies in order to investigate causal relationships. Another limitation is about the participants as they

\section{References}

Al Jabari, R. M. (2012). Relationships among self-esteem, cognitive and psychological flexibility, and psychological symptomatology (Master Thesis). Retriewed from

https://digital.library.unt.edu/ark:/67531/metadc177172/m2/1/high_res_ d/thesis.pdf

Argyle, M., \& Lu, L. (1990). The happiness of extraverts. Personal Individual Differences, 11(19), 1011-1017.

Arnett, J. J. (2000). Emerging adulthood: A theory of development from the late teens through the twenties. American Psychologist, 469-480.

Asıc1, E., \& İkiz, F. (2015). A pathway to happiness: Cognitive flexibility. Mebmet Akif Ersoy University Educational Faculty Journal, 1(35), 191-211.

Aslan, S. (2015). Development of Adjustment to University Life Scale. Hacettepe University Journal of Education, 30(04), 132-145.

Aydin, G., \& Tezer, E. (1991). The relationships among optimism, physical health problems and academic achievement. Psychology Journal, 7, 2-9.

Baker, R. W., \& Siryk, B. (1984). Measuring adjustment to college. Journal of Counseling Psychology, 31, 179-189.

Baker, S. (2004). Intrinsic, extrinsic, and motivational orientations: Their role in university adjustment, stress, well-being, and subsequent academic performance. Current Psychology, 23(3), 189-202.

Benn, I., Harvey, J. E., Gilbert, P., \& Irons, C. (2005). Social rank, interpersonal trust and recall of parental rearing in relation to homesickness. Personal Individual Difference, 38, 1813-1822.

Ben-Zur, H. (2003). Happy adolescents: The link between subjective wellbeing, internal resources, and parental factors. Journal of Youth and Adolescence, 32, 67-79.

Bing, Z. (2011). A relationship study on cognitive flexibility and school adaptation for the freshmen (Master's thesis). Retrieved from

https://search.proquest.com/pqdtglobal/docview/1874542152/A7658266 AA6D4846PQ/1?accountid $=11054$

Bilgin, M. (2009). The predictive factors of cognitive flexibility. Cukurova University Faculty of Education Journal, 3 (36), 142-157.

Bilgin, M. (2017). Relations to five factor personality model with cognitive flexibility in adolescents. Electronic Journal of Social Sciences, 16(62), 945954.

Buote, V., Pancer, S., Pratt, M., Adams, G., Birnie-Lefcovitch, S., Polivy, J., \& Wintre, G. M. (2007). The importance of friends, friendship and adjustment among 1st-year university students. Journal of Adolescent $\mathrm{R} e$ search, 22, 665-689. http://dx.doi.org/10.1177/0743558407306344

Cabras, C., \& Mondo, M. (2018). Coping strategies, optimism, and life satisfaction among first-year university students in Italy: Gender and age differences. Higher Education: The International Journal of Higher Education Research, 75(4), 643-654.

Cardom, R. D. (2016). The mediating role of cognitive flexibility on the relationship between cross-race interactions and psychological well-being (Doctoral dissertation). Retrieved from https://uknowledge.uky.edu/edp_etds/50 were chosen through the convenience sampling method. Undergraduates from different regions would have increased the generalizability of the research findings.

\section{Implications}

The present research provides a comprehension about the happiness of undergraduates by considering the relationships between optimism, cognitive flexibility, and adjustment to university life. As well as the findings of this study may be used for preventive counseling and guidance programs, it has also practical implications for happiness promotion suggesting that interventions focused on optimism and cognitive flexibility will enhance both adjustment to university life and happiness of undergraduates. Therefore, the study has the potential to provide a view for further research and practice.

Carver, C. S., \& Scheier, M. F. (1990). Origins and functions of positive and negative affect: A control-process view. Psychological Review, 97, 19-35. https://doi.org/10.1037//0033-295X.97.1.19.

Carver, C. S., \& Scheier, M. F. (1999). Themes and issues in the selfregulation of behavior. In R. S. Wyer, Jr. (Ed.), Advances in social cognition (Vol. 12). Mahwah, NJ: Erlbaum.

Carver, C. S, Scheier, M. F., \& Segerstrom, S. C. (2010). Optimism. Clinical $\begin{array}{lll}\text { Psychological Review, } & \text { 30(7), }\end{array}$ https://doi.org/10.1016/j.cpr.2010.01.006.

Carver, C. S., \& Scheier, M. F. (2014). Dispositional optimism. Trends in Cognitive $\quad$ Sciences., 18(6), 293-299 https://doi.org/10.1016/j.tics.2014.02.003.

Chang E. C. (1998). Dispositional optimism and primary and secondary appraisal of a stressor: controlling for confounding influences and relations to coping and psychological and physical adjustment. Journal of Personal and Social Psychology, 74, 1109-1120. https://doi.org/10.1037//0022-3514.74.4.1109.

Cheng, H. L. (2001). Causes and correlations of happiness and mental health among adolescents (Doctoral Dissertation). Retriewed from https://search.proquest.com/pqdtglobal/docview/1758963943/C709 A9E9DA2B430CPQ/28? accountid $=11054$

Choi,, J. (2016). Sustainable behavior: Study engagement and happiness among university students in South Korea. Sustainability, 8, 599.

Conversano, C., Rotondo, A., Lensi, E., Della, Vista O., Arpone, F., \& Reda, M. A. (2010). Optimism and its impact on mental and physical wellbeing. Clinical Practice \& Epidemiology in Mental Health, 6, 25-29.

Coups, E. J. (2003). A goal-based explanation of optimism's effects on well-being (Doctoral dissertation). Retrieved from

https://search.proquest.com/pqdtglobal/docview/305314121/fulltextPDF /820D2CD4B0EC42C2PQ/1?accountid=11054

Cousins, L. A., Tomlinson, R. M., Cohen, L. L., \& McMurtry, C. M. (2016). The power of optimism: Applying a positive psychology framework to pediatric pain. Pediatric Pain Letter, 18(1), 1-5.

Credé, M., \& Niehorster, S. (2012). Adjustment to college as measured by the student adaptation to college questionnaire: A quantitative review of its structure and relationships with correlates and consequences. Educational Psychology Review, 24(1), 133-165.

Çikrikci, Ö. (2018). The predictive roles of cognitive flexibility and error oriented motivation skills on life satisfaction. International Journal of Eurasia Social Sciences, 9(31), 717-727.

Daukantaite, D., \& Bergman, L. R. (2005). Childhood roots of women's subjective well-being: The role of optimism. European Psychologist, 10(4), 287-297. https://doi.org/10.1027/1016-9040.10.4.287. 
De Dreu, C. K. W., Baas, M., \& Nijstad, B. A. (2008). Hedonic tone and activation in the mood-creativity link: Towards a dual pathway to creativity model. Journal of Personality and Social Psychology, 94, 739-756.

Demirtaş, A. S. (2018). The predictive roles of emotion regulation strategies and self-esteem on happiness. Turkish Studies, 13(11). https://doi.org/10.7827/TurkishStudies.13465.

Dennis, J. P., \& Vander Wal, J. S. V. (2010). The cognitive flexibility inventory: Instrument development and estimates of reliability and validity. Cognitive Therapy and Research, 34, 241-253. https://doi.org/10.1007/s10608-009-9276-4.

Diener, E (1984). Subjective well-being. Psychological Bulletin, 95(3), 542-75.

Doğan-Laçin, B. G. (2015). Predictive roles of self-efficacy and coping strategies in cognitive flexibility among university students (Master's thesis). Retrieved from https://tez.yok.gov.tr/UlusalTezMerkezi/tezSorguSonucYeni.jsp

Doğan-Laçin, B. G., \& Yalçın, İ. (2018). Predictive roles of self-efficacy and coping strategies in cognitive flexibility among university students. Hacettepe University Journal of Education. https://doi.org/10.16986/HUJE.2018037424.

Doğan, T., \& Akınc1-Çötok, N. (2011). Adaptation of the short form of the Oxford happiness questionnaire into Turkish: A validity and reliability study. Turkish Psychological Counseling and Guidance Journal, 4(36), 165-172.

Doğan, T. (2013). The five factor personality traits and subjective wellbeing. Doğus University Journal, 14(1), 56-64.

Duy, B., \& Yildiz, M. A. (2017). The mediating role of self-esteem in the relationship between optimism and subjective well-being. Current Psychology. https://doi.10.1007/s12144-017-9698-1.

Dyson, R., \& Renk, K. (2006). Freshmen adaptation to university life: Depressive symptoms, stress, and coping. Journal of Clinical Psychology, 62(10), 1231-1244

Elias, H., Noordin, N. \& Mahyuddin, R. H. (2010). Achievement motivation and self-efficacy in relation to adjustment among university students. Journal of Social Sciences, 6(3), 333-339.

Fu, F., \& Chow, A. (2017). Traumatic exposure and psychological wellbeing: The moderating role of cognitive flexibility. Journal of Loss and Trauma, 22(1), 24-35. https://doi.10.1080/15325024.2016.1161428

Flynn D. \& Macleod S. (2015). Determinants of happiness in undergraduate university students. College Student Journal, 49, 452-460.

Gabrys, R. L., Tabri, N., Anisman, H., \& Matheson, K. (2018). Cognitive Control and Flexibility in the Context of Stress and Depressive Symptoms: The Cognitive Control and Flexibility Questionnaire. Frontiers in Psychology, 9, 2219. https://doi.10.3389/fpsyg.2018.02219

Gore, S., \& Aseltine, R. H. (2003). Race and ethnic differences in depressed mood following the transition from high school. Journal of Health and Social Behavior, 44, 370-389. https://doi.10.2307/1519785.

Gurvis, J., \& Calarco, A. (2007). Adaptability: Responding effectively to change. USA: Center for Creative Leadership.

Gülüm, İ. V., \& Dağ, İ. (2012). The Turkish adaptation, validity and reliability study of The Repetitive Thinking Questionnaire and The Cognitive Flexibility Inventory. Anatolian Journal of Psychiatry, 13, 216-223.

Gürbüz, E. K. \& Nartgün, Ş. S. (2018). Cognitive flexibility and self-efficacy levels of pedagogical formation program students. The Journal of International Social Research, 11(55), 628-640.

Halamandaris, K. F. \& Power, K. G. (1997). Individual differences, dysfunctional attitudes, and social support: A study of the psychosocial adjustment to university life of home students. Personality and Individual Differences, 22(1), 93-104.

Hanssen, M. M., Vancleef, L. M. G., Vlaeyen . W. S.,. Hayes, A. F., Schouten, E. G. W., \& Peters, M. L. (2014). Optimism, motivational coping and well-being: Evidence supporting the importance of flexible goal adjustment. Journal of Happiness Studies, 16, 1525-1537.

Hayes, A. F. (2009): Beyond Baron and Kenny: Statistical mediation analysis in the new millennium. Communication Monographs, 76(4), 408-420. Gürbüz, E. K. \& Nartgün, Ş. S. (2018). Cognitive flexibility and selfefficacy levels of pedagogical formation program students. https://doi.10.1080/03637750903310360

Hayes, A. F. (2017). Introduction to mediation, moderation, and conditional process analysis: A regression-based approach (2nd ed.). New York: Guilford Press.

Heo, J., Chun, S. Lee, S., \& Kim, J. (2016). Life satisfaction and psychological well-being of older adults with cancer experience: The role of opti- mism and volunteering. The International Journal of Aging and Human Development, 83(3), 274-289. https://doi.10.1177/0091415016652406.

Herrmann, L. (2007). Adjustment to college: The role of optimism, coping strategies, and parental attachment. Pace University, ProQuest Dissertations Publishing. from https://digitalcommons.pace.edu/dissertations/AAI3287857/

Hills, P., \& Argyle, M. (2002). The Oxford Happiness Questionnaire: A compact scale for the measurement of psychological well-being. Person ality and Individual Differences 33, 1073-1082.

Hirt, E. R., Devers, E. E., \& McCrea, S. M. (2008). I want to be creative: Exploring the role of hedonic contingency theory in the positive moodcognitive flexibility link. Journal of Personality and Social Psychology, 94, 214 230 .

Isaacowitz D. M. (2001). Optimism and subjective well-being in adulthood and old age (Doctoral dissertation). Retriewed from

https://search.proquest.com/pqdtglobal/docview/251113149/fulltextPDF /83C44D9DA4D84150PQ/1?accountid=11054

Isen, A. M. (2000). An influence of positive affect on decision making in complex situations: Theoretical issues with practical implications. Jour $\begin{array}{llll}\text { nal of Consumer Psychology, } & 11 & \text { (2), } & \text { 75-85. }\end{array}$ https://doi.10.1207/S15327663JCP1102_01.

Ji, H. \& Zhang, L. (2011). Research on college students' stresses and coping strategies. Asian Social Science, 7(10), 30-34.

Johnco C., Wuthrich V. M., Rapee R. M. (2014). The influence of cognitive flexibility on treatment outcome and cognitive restructuring skill acquisition during cognitive behavioural treatment for anxiety and depression in older adults: Results of a pilot study. Behav. Res. Ther. 57, 55-64. https://doi.10.1016/j.brat.2014.04.005

Johnson, B. T. (2016). The relationship between cognitive flexibility, coping, and symptomatology in psychotherapy (Master thesis). Retriewed from http://epublications.marquette.edu/theses_open/354

Johnson, K. J., Waugh, C. E., \& Fredrickson, B. L. (2010). Smile to see the forest: Facially expressed positive emotions broaden cognition. Cognition and Emotion, 24(2), 299-321.

Kaba, İ., \& Keklik, I. (2016). Students adaptation to university life, resilience and psychological symptoms. Hacettepe University Graduate School of Educational Sciences The Journal of Educational Research, 2(2), 98-113.

Kato, T. (2012). Development of the Coping Flexibility Scale: Evidence for the coping flexibility hypothesis. Journal of Counseling Psychology, 14(4), 353-363. https://doi.0.1037/a0027770

Koesten, J., Schrodt, P., \& Ford, D. J. (2009) Cognitive flexibility as a mediator of family communication environments and young adults' wellbeing, Health Communication, 24(1), 82-94. https://doi.10.1080/10410230802607024

Krypel, M. N., \& Henderson-King, D. (2010). Stress, coping styles, and optimism: Are they related to meaning of education in students' lives? Social Psychology of Education, 13, 409. https://doi.10.1007/s11218-0109132-0

Lee, D. \& Padilla, A. (2015). Predicting South Korean university students' happiness through social support and efficacy beliefs. International Journal for the Advancement of Counselling, 38. https://doi.10.1007/s10447015-9255-2.

Leung, B. W., Moneta, G. B. \& McBride-Chang, C. (2005). Think positively and feel positively: Optimism and life satisfaction in late life. Internation al Journal of Aging and Human Development, 61 (4) 335-365.

Lin, Y. (2013). The effects of cognitive flexibility and openness to change on college students' academic performance (Master's thesis). Retriewed from

https://search.proquest.com/pqdtglobal/docview/1433926373/fulltextPD $\mathrm{F} / 45 \mathrm{D} 01 \mathrm{BF} 762 \mathrm{~A} 1409 \mathrm{APQ} / 1$ ?accountid $=11054$

Linley, P. A., Maltby, J., Wood, A. M., Osborne, G., \& Hurling, R. (2009). Measuring happiness: The higher order factor structure of subjective and psychological well-being measures, Personality and Individual Differences, 47 (8), 878-884.

Marrero, R. J., Carballeira, M. \& González, J. A. (2014). Relationship between subjective well-being, optimism and demographic variables in college students of the University of San Luis Potosi in Mexico. Univer sitas Psychologica, 13(3), 1083-1098. https://doi.10.11144/Javeriana.UPSY13-3.rbso. 
Martin, M., \& Anderson, C. (1998). The Cognitive Flexibility Scale: Three validity studies. Communication Reports, 11, 1-9. https://doi.10.1080/08934219809367680.

Martin, M. M., \& Rubin, R. B. (1995). A new measure of cognitive flexibility. Psychological Reports, 76, 623-626.

Matthews, E. E., \& Cook, P. (2009). Relationships among optimism, wellbeing, self-transcendence, coping, and social support in women during treatment for breast cancer. Psycho-oncology, 18(7), 716-726. https://doi.10.1002/pon.1461.

Mroczek, D. K., \& Kolarz, C. M. (1998). The effect of age on positive and negative affect: A developmental perspective on happiness. Journal of Personality and Social Psychology, 75, 1333-1349.

Nowell, C. (2017). The influence of motivational orientation on the satisfaction of university students. Teaching in Higher Education, 22(7), 855866. https://doi.10.1080/13562517.2017.1319811.

Nurttila, S., Ketonen, E., \& Lonka, K. (2015). Sense of competence and optimism as resources to promote academic engagement. Procedia - Social and Behavioral Sciences, 171, 1017-1026.

Önen, A. S., \& Koçak, C. (2015). The effect of cognitive flexibility on higher school students' study strategies. Procedia-Social and Behavioral Sciences, 191(2), 2346-2350. https://doi.0.1016/j.sbspro.2015.04.680.

Pacheco, B., \& Kamble, D. S. (2016). The role of optimism in stress and coping of undergraduate students in Goa. The International Journal of Indian Psychology, 3(2), 60-68.

Perera, H. N., \& McIlveen, P. (2014). The role of optimism and engagement coping in college adaptation: A career construction model. Journal of $\mathrm{Vo}$ cational Behavior, 84(3), 395-404. https://doi.10.1016/j.jvb.2014.03.002.

Peterson, C. (2000). The future of optimism. The American Psychologist, 55, 44-55. https://doi.10.1037/0003-066X.55.1.44.

Preacher, K., \& Hayes, A. (2008). Asymptotic and resampling strategies for assessing and comparing indirect effects in multiple mediator models. Behavior Research Methods, 40, 879-891. https://doi.10.3758/BRM.40.3.879.

Pritchard, M. E., Wilson, G. S., \& Yamnitz, B. (2007). What predicts adjustment among college student? Journal of American College Health, 56, $15-21$.

Rahat, E., \& İlhan, T. (2015). Coping styles, social support, relational selfconstrual, and resilience in predicting students' adjustment to university life. Educational Sciences: Theory and Practice, 16, 187-208. https://doi.10.12738/estp.2016.1.0058.

Rubin, R., \& Martin, M. (1994). Development of a measure of interpersonal competence. Communication Research Reports, 11, 33-44. https://doi.10.1080/08824099409359938.

Ryff, C. D. (1989). Happiness is everything, or is it? Explorations on the meaning of psychological well-being. Journal of Personality and Social Psychology, 57, 1069-1081.

Sahai, A., \& Singh, A. (2017). A correlation study: The relationship between optimism and subjective well-being of education sector employees. Indian Journal of Positive Psychology, 8(3), 347-350.

Sapmaz, F., \& Doğan, T. (2013). Assessment of cognitive flexibility: Reliability and validity studies of Turkish version of the Cognitive Flexibility Inventory. Ankara University, Journal of Faculty of Educational Sciences, 46(1), 143-161.

Shapira, L. B., \& Mongrain, M. (2010). The benefits of self-compassion and optimism exercises for individuals vulnerable to depression. The Journal $\begin{array}{llll}\text { of } & \text { Positive } & \text { 377-389. }\end{array}$ http://dx.doi.org/10.1080/17439760.2010.516763

Scheier, M. F., \& Carver, C. S. (1985). Optimism, coping, and health: Assessment and implications of generalized outcome expectancies. Health Psychology, 4(3), 219- 247.

Scheier, M. F., \& Carver, C. S. (1988). A model of behavioral self-regulation: Translating intention into action. Advances in Experimental Social Psychology, 21(C), 303-346. https://doi.10.1016/S0065-2601(08)60230-0.

Scheier, M. F., \& Carver, C. S. (1992). Effects of optimism on psychological and physical well-being: Theoretical overview and empirical update. Cognitive Therapy and Research, 16(2), 201-228.

Scheier, M. F., Carver, C. S., \& Bridges, M. W. (1994). Distinguishing optimism from neuroticism (and trait anxiety, self-mastery, and selfesteem): A re-evaluation of the life orientation test. Journal of Personality and Social Psychology, 67, 1063- 1078

Seligman, M. E. P. (1990). Learned optimism. New York: Knopf.

Seligman, M. E. (2002). Authentic happiness: Using the new positive psychology' to realize your potential for lasting fulfillment. New York: Free Press.

Seligman, M. E., \& Csikszentmihalyi, M. (2000). Positive psychology: An introduction. American Psychologist, 55(1), 5-14. https://doi.10.1037/0003066X.55.1.5.

Shields, N. (2001) Stress, active coping and academic performance among persisting and non-persisting college students. Journal of Applied Biobehavioral Research, 6(2), 65-81.

Sürücü, M., \& Bacanlı, F. (2010). An examination of university adjustment according to psychological hardiness and demographic variables. Gazi University Journal of Gazi Educational Faculty, 30(2), 375-396.

Stevens, A. D. (2009). Social problem-solving and cognitive flexibility: Relations to social skills and problem behavior of at-risk young children. Seattle Pacific University.

Tabachnick, B. G., \& Fidell, L. S. (2013). Using Multivariate Statistics. Pearson, Boston

Tamir, M. (2009) What do people want to feel and why? Pleasure and utility in emotion regulation. Current Directions in Psychological Science, 18, 101105.

Theobald, T., \& Cooper, C. (2012). Doing the right thing the importance of wellbeing in the workplace. Palgrave Macmillan, London.

Vazquez, V. (2009). Just world beliefs, optimism and well-being (Doctoral dissertation). Retriewed from https://search.proquest.com/pqdtglobal/docview/304922245/fulltext $\mathrm{PDF} / 87 \mathrm{C} 29 \mathrm{DEF} 2 \mathrm{D} 7 \mathrm{~F} 46 \mathrm{ECPQ} / 1$ ? accountid $=11054$

Wimberly, S. R., Carver, C. S., \& Antoni, M. H., (2008). Effects of optimism, interpersonal relationships, and distress on psychosexual wellbeing among women with early stage breast cancer. Psychology \& Health, 23(1), 57-72.

World Health Organization (2004). Promoting mental health: Concepts emerging evidence and practice. Summary report, World Health Organization, Geneva.

Yue, X. D., Hao, X., \& Goldman, G. L. (2010). Humor styles, dispositional optimism and mental health, among undergraduates in Hong Kong and China. Journal of Psychology in Chinese Society, 11, 61-68.

Zhang, J. H. (2011). Relationships between cognitive flexibility and coping strategies of bigh school students (Master's Thesis). Retriewed from

https: / / epublications.marquette.edu/cgi/viewcontent.cgi?article=1350\&con text=theses_open

Ziapour, A., Khatony, A., Jafari, F. \& Kianipour, N. (2018). Correlation of personality traits with happiness among university students. Journal of Clinical and Diagnostic Research, 12(4), 26-29. 